\title{
Risk factors for urinary incontinence in institutionalized elderly
}

Fatores de risco para incontinência urinária em idosos institucionalizados

Factores de riesgo para incontinencia urinaria en ancianos institucionalizados

Cíntia Lira Borges, ,* Bruna Karen Cavalcante Fernandes², Maria Lígia Silva Nunes Cavalcante², Rachel Gabriel Bastos Barbosa ${ }^{3}$, Arnaldo Aires Peixoto Junior', Luciana Catunda Gomes de Menezes²

ORCID IDS

Borges CL (D) https://orcid.org/0000-0002-5204-0173

Fernandes BKC (iD https://orcid.org/0000-0003-2808-7526

Cavalcante MLSN DiD https://orcid.org/0000-0003-4830-9413

Barbosa RGB (D) https://orcid.org/0000-0003-4205-6910

Peixoto Junior AA (iD https://orcid.org/0000-0001-6225-934X

Menezes LCG (iD https://orcid.org/0000-0002-7828-9065
HOW TO CITE

Borges CL, Fernandes BKC, Cavalcante MLSN, Barbosa RGB, Peixoto Junior AA, Menezes LCG. Risk factors for urinary incontinence in institutionalized elderly. ESTIMA, Braz. J. Enterostomal Ther., 16: e0619. https://doi.org/10.30886/estima.v16.726 IN

\begin{abstract}
Objectives: To analyze the risk factors for urinary incontinence (UI) in institutionalized elderly. Methods: Cross-sectional, analytical, documentary study done by collection in 203 medical records of a long-stay institution in northeastern Brazil. An instrument for sociodemographic and health characterization and the values of the Mini Mental State Examination (MMSE) were used. The data were analyzed from the descriptive, inferential and multiple logistic regression. Results: The prevalence of UI was $42.36 \%$ and higher in women (66.28\%), older (mean: 79.62 years) and dependent (89.53\%). There was an association between age $(p=0.01)$, sex $(p=0.024)$, marital status $(p=0.007)$, religion $(p=0.015)$, with whom resided before institutionalization $(p=0.033)$, degree of dependency $(p<0.001)$, MMSE values $(p<0.001)$ and cardiovascular $(p<0.001)$ and neurological diseases $(p<0,001)$. The risk factors for $U$ I were number of diseases $(O R=1.17 ; 95 \%$ $\mathrm{Cl}=1.02-1.34)$, consumption of five to nine medications $(\mathrm{OR}=4.07,95 \% \mathrm{Cl}=1.14-14.52)$, single $(\mathrm{OR}=2.09,95 \% \mathrm{Cl}=1.30-8.01)$, dependent $(\mathrm{OR}=3.27,95 \% \mathrm{Cl}=1.33-8.04)$ and had a low MMSE score $(\mathrm{OR}=0.88,95 \% \mathrm{Cl}=0.85-0.93)$. Conclusion: The results reveal the importance of studying UI in this population to identify early risk factors that can be prevented.
\end{abstract}

DESCRIPTORS: Urinary incontinence; Elderly; Homes for the Aged; Risk factors; Prevalence; Stomatherapy.

1.Universidade Estadual do Ceará - Programa de Pós-Graduação em Saúde Coletiva - Fortaleza/CE - Brazil.

2.Universidade Estadual do Ceará - Programa Pós-Graduação em Cuidados Clínicos em Enfermagem e Saúde - Fortaleza/CE - Brazil.

3.Universidade Federal do Ceará - Departamento de Enfermagem - Fortaleza/CE, Brazil.

4.Centro Universitário Christus - Departamento de Medicina - Fortaleza/CE - Brazil.

*Correspondence author: cintialiraborges@yahoo.com.br

Received: Feb. 26, 2019 | Accepted: Apr. 22, 2019 


\section{RESUMO}

Objetivo: Analisar os fatores de risco para incontinência urinária (IU) em idosos institucionalizados. Métodos: Estudo transversal, analítico, documental realizado por coleta em 203 prontuários de uma instituição de longa permanência no nordeste do Brasil. Foram utilizados um instrumento para caracterização sociodemográfica e de saúde e os valores do Mini Exame do Estado Mental (MEEM). Os dados foram analisados a partir da estatística descritiva, inferencial e por regressão logística múltipla. Resultados: A prevalência de IU foi de 42,36\% e maior em mulheres (66,28\%), mais velhos (média: 79,62 anos) e dependentes (89,53\%). Houve associação entre idade $(p=0,01)$, sexo $(p=0,024)$, estado civil $(p=0,007)$, religião $(p=0,015)$, com quem residia antes da institucionalização ( $p=0,033)$, grau de dependência ( $p<0,001)$, valores do MEEM $(p<0,001)$ e doenças cardiovasculares $(p<0,001)$ e neurológicas $(p<0,001)$. Os fatores de risco para IU foram quantidade de doenças [odds ratio $(O R)=1,17$; intervalo de confiança de 95\% (IC95\%) = 1,02-1,34], consumo de cinco a nove medicamentos (OR = 4,07; IC95\% = 1,14-14,52), ser solteiro $(O R=2,09 ;$ IC95\% = 1,30-8,01), dependente $(O R=3,27$; IC95\% = 1,33-8,04) e ter baixa pontuação no MEEM (OR = 0,88; IC95\% = 0,85-0,93). Conclusão: Os resultados revelam a importância de estudar IU nessa população para identificar precocemente os fatores de risco passíveis de prevenção.

DESCRITORES: Incontinência urinária; Idoso; Instituição de longa permanência para idosos; Fatores de risco; Prevalência; Estomaterapia.

\section{RESUMEN}

Objetivo: Analizar los factores de riesgo para la incontinencia urinaria (IU) en ancianos institucionalizados. Métodos: Estudio transversal, analítico, documental realizado por colecta en 203 prontuarios de una institución de larga permanencia en el nordeste de Brasil. Se utilizó un instrumento para caracterización sociodemográfica y de salud y los valores del Mini Examen del Estado Mental (MEEM). Los datos fueron analizados a partir de la estadística descriptiva, inferencial y por regresión logística múltiple. Resultados: La prevalencia de IU fue de 42,36\% y mayor en mujeres (66,28\%), más viejos (promedio: 79,62 años) y dependientes (89,53\%). Hubo asociación entre edad ( $p=0,01)$, género $(p=0,024)$, estado civil $(p=0,007)$, religión $(p=0,015)$, con quienes residía antes de la institucionalización ( $p=0,033)$, grado de dependencia $(p<0,001)$, valores del MEEM $(p<0,001)$ y enfermedades cardiovasculares $(p<0,001)$ y neurológicas $(p<0,001)$. Los factores de riesgo para IU fueron la cantidad de enfermedades [odds ratio $(\mathrm{OR})=1,17$; el intervalo de confianza del 95\% (IC95\%) =1,02-1,34], el consumo de cinco a nueve medicamentos $(O R=4,07, I C 95 \%=1,14-14,52)$, ser soltero $(O R=2,09 ; \mathrm{IC} 95 \%=1,30-8,01)$, dependiente $(\mathrm{OR}=3,27$; IC95\% = 1,33-8,04) y tener baja puntuación en el MEEM $(\mathrm{OR}$ = 0,88; IC95\% = 0,85-0,93). Conclusión: Los resultados revelan la importancia de estudiar IU en esa población para identificar precozmente los factores de riesgo pasibles de prevención.

DESCRIPTORES: Incontinencia urinaria; Ancianos; Hogares para ancianos; Factores de riesgo; Prevalencia; Estomaterapia.

\section{INTRODUCTION}

Urinary incontinence (UI) is a common problem among institutionalized elderly, with relevant consequences for the quality of life (QoL) and health costs ${ }^{1}$. Research indicates that UI may be the reason for admission to long-term institutions for the elderly ${ }^{2}$ or can be easily developed after institutionalization.

The prevalence of UI at these sites can range from $35.9^{3}$ to $72 \%^{4}$, considerably higher when compared to the elderly in the community, in which the prevalence is $3.5^{5}$ to $10,3 \%^{6}$. This problem represents high costs for society, the family and the elderly. In the United States, it is estimated that in 2007, about US\$ 65.9 billion was spent in 2015, US\$76.2 billion, and projections for 2020 are about US $\$ 82.6$ billions for the health system and for patients to purchase personal items for routine care with UI7.
The causes of UI in the elderly are diverse and in women, they are more associated with age, body mass index, parity, smoking, hysterectom ${ }^{8}$, hypertension, diabetes, and menopause ${ }^{9}$. In men, it can occur due to age ${ }^{9}$, to benign prostatic hyperplasia ${ }^{10}$ or in the postoperative of surgeries, such as transurethral resection, open prostatectomy, and retropubic radical ${ }^{11}$.

By definition, UI means involuntary loss of urine ${ }^{12}$. There are two types of IU: transient and persistent. The first is reversible, coming from external conditions that can be treated ${ }^{13}$. The second one occurs even after transient problems are solved and divided into four groups: urgency (abrupt loss of urine after strong urge to urinate); (involuntary loss associated with physical exertion); overflow (when urine leakage and leakage occurs after exceeding total bladder storage capacity); and functional (relates to the inability or unwillingness to go to the bathroom $)^{13}$. 
UI has disastrous consequences for the individual's life, especially the elderly, who often believe that UI is part of natural aging and neglects the problem. However, this is a chronic and debilitating condition that causes physical, social and emotional losses. UI is an important marker of mortality and is related to geriatric syndromes and fragility, and may be a real determinant of survival in the institutionalized population ${ }^{1}$.

It is important to identify the risk factors for UI so that prevention strategies and effective treatments are implanted early in order to avoid or control $\mathrm{UI}^{3}$. It is recommended to perform the functional and health evaluation of the elderly, including mobility, transfer, toilet, disease and medication profile and causes of UI, in order to plan behavioral therapies such as programmed urination ${ }^{14}$. These measures combined with physical activities and specific exercises can improve functional status and UI status among the elderly ${ }^{3}$. Thus, based on the wide evaluation of the multi-professional team, it is possible to detect the type of UI and to individualize the care plan according to the needs of each elderly person.

In addition, the nursing team has an important role in care for the incontinent elderly. There are numerous nursing interventions that can be determinant for the quality of care in institutions, such as the presence of nurses with continence training, provision of UI leaflets to residents and caregivers, bladder training and relaxation and the feasibility of organized and documented management protocols to guarantee UI products - disposable diapers, comfortable clothes and disposable or washable cushions ${ }^{15}$. Nurses must abandon the idea that UI is always a normal consequence of aging and believes that it is necessary to actively prevent it in nursing practice ${ }^{15}$.

The objective of this study is to analyze the risk factors for UI in institutionalized elderly.

\section{METHODS}

A cross-sectional, quantitative, documentary, retrospective study using 203 medical records of elderly people living in a non-profit long-stay institution in northeastern Brazil. The site serves elderly people of all social classes, predominantly those in situations of social vulnerability, being the admission of their own will, violence or referral of public organs and institutions. The collection took place between the 1st and the 30th of September 2016.

Data were collected from a sociodemographic and health characterization instrument that contained questions about age, sex, marital status, schooling, religion, motive and time of institutionalization, with whom resided before institutionalization, visits, diseases, medications, and degree of dependency. In addition, the results of the last evaluation of the Mini Mental State Examination (MMSE) ${ }^{16}$, which is performed quarterly in this institution by health professionals.

UI, outcome variable, was defined according to the specifications of the diagnoses and the list of medical problems of the medical records. Although there is information about the UI specification, for example, emergency UI and mixed UI, in this study, for statistical analysis, the UI variable was dichotomous, dividing into presence or absence, regardless of the type

Regarding the variable with whom resided before institutionalization, the category "other" referred to friends, relatives, shelters or health institutions. Likewise, the reason for institutionalization in the other category evidenced elderly people who suffered violence were street dwellers, were transferred from other shelters or referred by the Public Prosecutor. The time of institutionalization was measured in months and the drugs were distributed in three categories, which were divided according to the definition of polypharmacy (from five to nine medications) and excessive polypharmacy (more than 10 medications) ${ }^{17}$.

The degree of dependence was characterized by levels defined in I. independent elderly; II. elderly with dependence on up to three basic activities of daily living, with or without controlled cognitive alteration; III. elderly people with a dependence on all self-care activities and/or with cognitive impairment ${ }^{18}$. This classification is updated monthly, since it is a mandatory item of the technical regulation of the Agência Nacional de Vigilância Sanitária - ANVISA (National Agency of Sanitary Surveillance) for the operation of long-term institutions for the elderly, as well as, constantly, the place is subject to the supervision, evaluation, and social control and needs evaluation of the actions and care of the residents.

MMSE is a test that assesses cognitive function quickly, conveniently and simply ${ }^{16}$. It is used in different 
contexts of clinical practice for cognitive screening, identifying the main functions that deserve to be investigated $^{19}$. The cut-off point of the MMSE was not used in this study since the variable was numerical, not categorical.

To prepare the table and categorize the types of diseases, a list was made of the diseases of all the elderly, which were distributed according to the classes: cardiovascular, neurological, psychiatric, osteomuscular, endocrine and renal.

The analysis was performed using the Stata version 11.0 program. Data were expressed as means, standard deviation, minimum and maximum for continuous variables, and frequencies and percentages for categorical variables. The Shapiro-Wilk test was used, with a significance level of $<0.05$. It was concluded that all continuous variables (age, institutionalization time and the number of diseases) were not in the normality pattern, rejecting the hypothesis. Therefore, for the bivariate association between these and the UI, the non-parametric Mann-Whitney test was applied. For the association of UI and categorical variables, Pearson's chi-square test was used.

In the final analysis of the associated factors, the logistic regression model was used. For modeling, marital status (single and others), religion (Catholic and others), the reason for institutionalization (alone and others) and degree of dependence (independent/grade I and dependent/grades II and III) were transformed into dichotomous variables.

Firstly, an initial reduced model with basal categories was constructed from simple logistic regression. Variables with a descriptive level of up to $20 \%(\mathrm{p}<0.20)$ were included in this model. At that time, the variables institutionalization and visiting time were excluded. The next step was the creation of the multivariate model adjusted for the degree of dependence, with those with $\mathrm{p} \leq 0.2$ being excluded, with gender excluded $(p=0.275)$, institutionalization reason $(p=0.867)$ and with those residing before institutionalization $(\mathrm{p}=0.282)$. It should be noted that the variable number of diseases, at this stage, presented $p=0.246$, but was maintained.

The overall adjustment of each model was verified by the likelihood ratio test, the initial and final multiple logistic regression model is considered equal ( $p=0.43$ ). For this reason, the one with the least variables was adopted. In the final model, those variables remained at $\mathrm{p}<0.05$, in addition to the marital status variable that, despite having $\mathrm{p}=0.066$, was conserved. The association measure was represented by the odds ratio (OR), with a $95 \%$ confidence interval $(95 \% \mathrm{CI})$.

The ethical recommendations on research with human beings were complied with, according to Resolution 466/2012 of the Ministério da Saúde (Ministry of Health $)^{20}$. The research was approved by the Ethics Committee of the Universidade Estadual do Ceará (CAAE: 12390513.8.0000.5534; opinion: 1.532.812).

\section{RESULTS}

Prevalence of female elderly (57.14\%) with a mean age of 77.59 years $( \pm 8.99)$. The prevalence of UI was $42.36 \%$ and higher in older women $(66.28 \%)$, older (mean: 79.62 years) and dependent (89.53\%). Table 1 shows a statistically significant association between age $(p=0.01)$, gender $(p=0.024)$, marital status $(p=0.007)$, religion $(p=0.015)$ and whom lived with before institutionalization $(p=0.033)$.

In Table 2, there was a relationship between degree of dependence $(\mathrm{p}<0.001)$ and values of MMSE $(\mathrm{p}<0.001)$.

Table 3 shows that there was a significant relationship between UI and cardiovascular ( $p<0.001)$ and neurological diseases $(\mathrm{p}<0.001)$.

In the univariate analysis, in the simple model, shown in Table 4, only two variables, visit and institutionalization time was not related to the UI outcome. In the multivariate model adjusted for the degree of dependence, all variables remained, except for gender, the reason for institutionalization, time of institutionalization and with whom resided before institutionalization.

In the final logistic regression model, the following variables were preserved in civil status $(\mathrm{OR}=2.09,95 \%$ $\mathrm{CI}=1.30-8.01)$, diseases $(\mathrm{OR}=1.17,95 \% \mathrm{CI}=1,02-1,34)$. Medicines [from one to four $(\mathrm{OR}=3.90,95 \% \mathrm{CI}=0.98$ 15.46), and from five to nine $(\mathrm{OR}=4.07,95 \% \mathrm{CI}=1.14$ 14.52)], degree of dependence $(\mathrm{OR}=3.27,95 \% \mathrm{CI}=1.33$ 8.04) and MMSE (OR $=0.88,95 \% \mathrm{CI}=0.85-0.93)$. The greatest amount of diseases, polypharmacy, being dependent and unmarried are important risk factors for UI involvement. The MMSE values were inversely proportional to the 
Table 1. Relationship between the social profile and institutionalization of the institutionalized elderly and urinary incontinence (UI), Fortaleza, Ceará State, Brazil, 2016.

\begin{tabular}{|c|c|c|c|}
\hline \multirow{2}{*}{ Independent variables } & \multicolumn{2}{|c|}{ Urinary incontinence } & \multirow{2}{*}{ p-value } \\
\hline & Absence $\mathrm{f}(\%)$ & Presence $\mathrm{f}(\%)$ & \\
\hline Age (minimum: 60; maximum: 103 anos) & $76.09( \pm 7.89)^{*}$ & $79.62( \pm 9.99)^{*}$ & $0.01^{\dagger}$ \\
\hline Gender & & & $0.024^{\ddagger}$ \\
\hline Male & $58(49.57)$ & $29(33.72)$ & \\
\hline Female & $59(50.43)$ & $57(66.28)$ & \\
\hline Marital Status & & & $0.007^{\ddagger}$ \\
\hline Single & $49(41.88)$ & $52(60.47)$ & \\
\hline Separated/divorced & $39(33.33)$ & $11(12.79)$ & \\
\hline Widowed & $26(22.22)$ & $20(23.26)$ & \\
\hline Married & $03(2.56)$ & $03(3.49)$ & \\
\hline Religion & & & $0.015^{\ddagger}$ \\
\hline Catholic & $93(79.49)$ & $79(91.86)$ & \\
\hline Others & $24(20.51)$ & $07(8.14)$ & \\
\hline Gets visited & & & $0.848^{\ddagger}$ \\
\hline Yes & $75(64.10)$ & $54(62.79)$ & \\
\hline No & $42(35.90)$ & $32(37.21)$ & \\
\hline With whom they lived before institutionalization & & & $0.033^{\ddagger}$ \\
\hline Alone & $57(48.72)$ & $31(36.05)$ & \\
\hline Children & $13(11.11)$ & $22(25.58)$ & \\
\hline Spouses & $11(9.40)$ & $05(5.81)$ & \\
\hline Others & $36(30.77)$ & $28(32.56)$ & \\
\hline Reason for institutionalization & & & $0.062^{\ddagger}$ \\
\hline Own will & $43(36.75)$ & $21(24.42)$ & \\
\hline Other reasons & $74(63.25)$ & $65(75.58)$ & \\
\hline Time of institutionalization (minimum: 6, maximum: 648 months) & $91.94( \pm 88.50)^{*}$ & $105.73( \pm 120.83)^{*}$ & $0.685^{\dagger}$ \\
\hline
\end{tabular}

*: mean; t: Mann-Whitney test; ł: chi-square test.

Table 2. Relationship between the health profile of the institutionalized elderly and the urinary incontinence (UI), Fortaleza, Ceará, Brazil, 2016

\begin{tabular}{|c|c|c|c|}
\hline \multirow{2}{*}{ Independent variables } & \multicolumn{2}{|c|}{ Urinary incontinence } & \multirow{2}{*}{$\mathrm{p}$-value } \\
\hline & Absence $f(\%)$ & Presence $f(\%)$ & \\
\hline Number of diseases (minimum: 2; maximum: 17) & $5.76( \pm 2.64)^{\star}$ & $6.52( \pm 3.43)^{\star}$ & $0.219^{\dagger}$ \\
\hline Medicines & & & $0.073^{\ddagger}$ \\
\hline 1 to 4 & $39(33.33)$ & $34(39.53)$ & \\
\hline 5 to 9 & $57(48.72)$ & $46(53.49)$ & \\
\hline 10 to 16 & $21(17.95)$ & $6(6.98)$ & \\
\hline Degree of dependency & & & $<0,001^{\ddagger}$ \\
\hline 1 & $64(54.7)$ & $09(10.47)$ & \\
\hline 2 & $53(45.3)$ & $12(13.95)$ & \\
\hline 3 & - & $65(75.58)$ & \\
\hline Mini Mental State Examination (minimum: 0; maximum: 30 ) & $17.70( \pm 8.20)^{\star}$ & $6.96( \pm 7.90)^{\star}$ & $<0,001^{\ddagger}$ \\
\hline
\end{tabular}

*: mean; †: Mann-Whitney test; ł: chi-square test. 
Table 3. Relationship between disease classes and urinary incontinence (UI) in institutionalized elderly, Fortaleza, Ceará State, Brazil, 2016.

\begin{tabular}{|c|c|c|c|}
\hline \multirow{2}{*}{ Diseases } & \multicolumn{2}{|c|}{ Urinary incontinence } & \multirow{2}{*}{$p$-value } \\
\hline & Absence $f(\%)$ & Presence $\mathrm{f}(\%)$ & \\
\hline Cardiovascul & $86(57.2)$ & $42(32.8)$ & $<0,001^{*}$ \\
\hline Neurological & $46(42.2)$ & $63(57.8)$ & $<0,001^{*}$ \\
\hline Psychiatric & $57(55.9)$ & 45 (44.1) & 0.611 * \\
\hline Osteomuscular & $47(54)$ & $40(46)$ & $0.367 \star$ \\
\hline Endocrine & $46(66.7)$ & $23(33.3)$ & $0.62^{\star}$ \\
\hline Renal & $22(73.3)$ & $08(26.7)$ & $0.59 *$ \\
\hline
\end{tabular}

*chi-square test

Table 4. Factors associated with the presence of urinary incontinence (UI) in institutionalized elderly in the simple logistic regression model for each independent variable and the initial multivariate model adjusted for the degree of dependence, Fortaleza, Ceará state, Brazil, 2016.

\begin{tabular}{|c|c|c|c|c|c|c|}
\hline \multirow{2}{*}{ Variables (basal category) } & \multicolumn{3}{|c|}{ Simple model } & \multicolumn{3}{|c|}{ Adjusted multivariate model } \\
\hline & ORg & $\mathrm{Cl}$ & p-value & ORa & $\mathrm{Cl}$ & p-value \\
\hline Age & 1.04 & $1.01-1.08$ & 0.006 & 1.03 & $0.99-1.06$ & 0.076 \\
\hline Gender (male) & 1.93 & $1.08-3.43$ & 0.025 & 1.04 & $0.75-2.73$ & 0.275 \\
\hline Marital status (others) & 2.12 & $1.20-3.74$ & 0.009 & 1.73 & $0.92-3.26$ & 0.088 \\
\hline Religion (others) & 2.91 & $1.19-7.11$ & 0.019 & 3.12 & $1.18-8.21$ & 0.021 \\
\hline Gets visited (doesn't) & 0.94 & $0.53-1.68$ & 0.848 & - & - & - \\
\hline With whom they lived before institutionalization (alone) & 1.68 & $0.95-2.98$ & 0.073 & 1.41 & $0.74-2.68$ & 0.283 \\
\hline Reason for institutionalization (own will) & 1.79 & $0.96-3.34$ & 0.063 & 0.93 & $0.45-1.96$ & 0.867 \\
\hline Time of institutionalization & 1.00 & $0.99-1.00$ & 0.350 & - & - & - \\
\hline Number of diseases & 1.08 & $0.99-1.19$ & 0.078 & 1.06 & $0.95-1.17$ & 0.246 \\
\hline \multicolumn{7}{|l|}{ Medicines (10 to 18) } \\
\hline 1 to 4 & 3.05 & $1.10-8.43$ & 0.032 & 3.24 & $1.08-9.66$ & 0.035 \\
\hline 5 to 9 & 2.82 & $1.05-7.57$ & 0.039 & 3.76 & $1.29-10.97$ & 0.015 \\
\hline Degree of dependency (I) & 10.33 & $4.73-22.54$ & 0.000 & 10.33 & $4.73-22.54$ & $<0,001$ \\
\hline Mini Mental State Examination & 0.86 & $0.83-0.90$ & 0.000 & 0.89 & $0.85-0.93$ & $<0,001$ \\
\hline
\end{tabular}

$\mathrm{Cl}=$ Confidence Interval; ORa = Odds Ratio adjusted; ORg = Odds Ratio gross

Table 5. Factors associated with the presence of urinary incontinence (UI) in institutionalized elderly in the initial and final multiple logistic regression model, Fortaleza, Ceará state, Brazil, 2016.

\begin{tabular}{|c|c|c|c|c|c|c|}
\hline \multirow{2}{*}{ Variables (basal category) } & \multicolumn{3}{|c|}{ Initial multivariate model } & \multicolumn{3}{|c|}{ Final multivariate model } \\
\hline & ORg & $\mathrm{Cl}$ & $\mathrm{p}$-value & ORa & $\mathrm{Cl}$ & p-value \\
\hline Age & 1.00 & $0.96-1.04$ & 0.777 & - & - & - \\
\hline Marital status (others) & 1.99 & $0.95-4.17$ & 0.066 & 2.09 & $1.00-4.33$ & 0.047 \\
\hline Religion (others) & 1.91 & $0.66-5.54$ & 0.231 & - & - & - \\
\hline Number of diseases & 1.16 & $1.01-1.33$ & 0.034 & 1.17 & $1.02-1.34$ & 0.023 \\
\hline \multicolumn{7}{|l|}{ Medicines (10 to 18) } \\
\hline 1 to 4 & 3.78 & $0.94-15.20$ & 0.061 & 3.90 & $0.98-15.46$ & 0.052 \\
\hline 5 to 9 & 3.73 & $1.03-13.49$ & 0.044 & 4.07 & $1.14-14.52$ & 0.030 \\
\hline Degree of dependency $(\mathrm{I})$ & 3.19 & $1.28-7.97$ & 0.013 & 3.22 & $1.30-8.01$ & 0.012 \\
\hline Mini Mental State Examination & 0.89 & $0.84-0.93$ & 0.000 & 0.88 & $0.84-0.93$ & $<0,001$ \\
\hline
\end{tabular}

$\mathrm{Cl}=$ Confidence Interval; ORa = Odds Ratio adjusted; ORg = Odds Ratio gross. 
presence of UI, so that the fewer points in the cognitive test, the greater the chances of having UI.

\section{DISCUSSION}

The prevalence of UI did not appear to be inconsistent

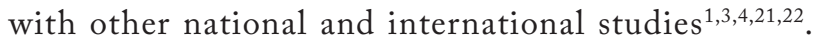
Although the literature presents significant differences about the UI between the genders in the community, females have a relatively double frequency of acquiring UI compared to the male ${ }^{23,24}$, in institutions, on the contrary, is similar to the variation of prevalence between the genders. In the elderly men, it varies from $33.9^{4} \mathrm{a}$ $60,3 \%{ }^{21}$, and, in elderly women, from $31,5^{4}, 47,5^{22}$ and $59,2 \%{ }^{21}$. It is believed that this difference from the community to the long-term institution is justified because the elderly men are more prone to a greater number of comorbidities, polypharmacy and physical restrictions that interfere with the mobility, nutrition, and use of the bathroom ${ }^{14}$. In this study, women $(\mathrm{p}=0.024)$ and older $(\mathrm{p}=0.01)$ predominated.

Although there is no great difference in the frequency of UI among the elderly male and female, it is worth noting that the risk of death associated with UI of institutionalized elderly men, users of polypharmacy and with some degree of dependence is higher than among elderly women in the same condition ${ }^{1}$. It should be emphasized that the length of stay is also a predictor of UI severity ${ }^{4}$.

$\mathrm{UI}$ is reported by many as a disabling and embarrassing condition. Being ill or ashamed of having the disease and asking for help can negatively affect care seeking behaviors ${ }^{25}$. However, by living with the problem for a long time, stigma and social rejection can no longer be a substantial barrier and become key factors in the search for health care ${ }^{25}$. In institutions of a long stay, even by the emotional and social fragility that surrounds these environments, the policy of prevention must be redoubled. Professionals should not only wait for the elderly to report the problem spontaneously, but to stimulate self-care, to be available for the demands, and to actively seek out the common signs and symptoms that cover UI in a subtle way and in dialogue with the seniors.

In the coming years, the number of elderly people living in long-term institutions living alone will increase. ${ }^{26}$. Living alone has a direct impact on the health status of the elderly, who may have more illnesses and disabilities ${ }^{27}$. For many elderly males, living alone results in a lack of social support, cognitive disorders, depression, chronic illness, and falls ${ }^{27}$. For the elderly, living alone and being single may represent the occurrence of falls, multiple diseases, depression, and chronic pain ${ }^{27}$. Being single, too, is key to restraining the elderly at home ${ }^{5}$. In this study, being single corresponded to a 2.09 higher odds of having UI compared to widowed, separated, divorced, and married. And living alone before institutionalization ( $p=0.033)$ was related to UI.

Several studies report that the presence of multiple comorbidities, especially cardiovascular and neurological, is a risk factor for UI. A Brazilian study found that stroke $(\mathrm{OR}=1.62)$ and Alzheimer's disease $(\mathrm{OR}=1.38)$ were the only positively associated with $\mathrm{UI}^{21}$ and that elderly residents of institutions with severe cognitive decline had an increased risk $(\mathrm{OR}=1.92)$ for developing $\mathrm{UI}^{21}$. In Spain, a cohort found that $80.6 \%$ of elderly incontinent residents had dementia ( $\mathrm{p}<0.001) 1$ and that elderly patients with heart failure $(\mathrm{OR}=1.88)$ and arrhythmias $(\mathrm{OR}=1.51)$ had a higher risk of mortality related to $\mathrm{UI}^{1}$. The present study detected a significant association between UI and the cardiovascular and neurological diseases class and risk of 1.17 to develop UI in those with more diseases.

Polypharmacy, defined as the use of multiple drugs or the use of more than one unnecessary drug, is a growing concern in the geriatric population ${ }^{28}$. Current evidence indicates that use is greater in long-term institutions and that nearly $50 \%$ of the elderly take one or more dispensable medication ${ }^{28}$. Many of these can cause increased urinary frequency ${ }^{29}$.

In the multiple regression model, polypharmacy $(\mathrm{OR}=4.07)$ was a risk factor for UI. The assessment of health professionals is essential in order to identify whether UI is manifested as a potential side effect of prescribed drugs. This is because it contributes to the reduction of prescribing cascade, which occurs when a new drug is added to treat essentially a side-factor of therapy already implemented ${ }^{30}$. This finding calls attention to intensifying the supervision of drugs that can corroborate the problem.

In long-term care facilities, a dependency is a direct determinant of UI. In the present study, a triple risk was observed among dependent elderly people for UI 
development. One study confirms the risk of 3,6 and 5,34 dependent elderly people acquiring UI and indicates that $90.47 \%$ of the elderly dependents had UI ${ }^{21}$.

Functional and mobility decline may justify the appearance of UI as a result of inaccessible toilets, inability to remove clothing in time, pelvic muscle incoordination, and other multifactorial causes ${ }^{3}$. UI can also limit patients' mobility, favoring a less active lifestyle, compromising personal relationships, generating, in the long term, depression, disability, and death ${ }^{1}$.

It is emphasized that the pelvic floor muscles act as part of the abdominopelvic unit, so exercises that integrate strength and coordination of the trunk or abdominal muscles provide efficient functioning of the pelvic floor muscle, preventing IU episodes ${ }^{3}$; in addition, they contribute to minimizing the advance of dependency levels and improving mobility.

UI may precede or accompany the onset of neurological conditions, including Alzheimer's disease, multi-infarct dementia, stroke, and Parkinson's disease ${ }^{31}$. The function of the micturition center in the brainstem is controlled by the frontal lobe and, in the context of neurodegenerative diseases or cerebrovascular accident, frontal cortex dysfunction occurs, giving rise to $\mathrm{IU}^{32}$.

Other evidence agrees with this study when they report that the prevalence of UI increases with decreasing MMSE scores ${ }^{31}$. The effect of cognitive performance on UI and the bidirectional aspect between these two conditions are well defined in the literature ${ }^{32}$.In addition, older and dependent elderly residents of institutions have lower cognitive status compared to the community ${ }^{33}$.

It is revealed that nursing care to the UI, in all cases performed by trained professionals, positively affects the severity of UI and the impact of $\mathrm{QoL}^{34}$. The nurse should know the aspects associated with UI, as well as proceed to early intervention, understanding that the results in the elderly are slow, but must be sustained to provide independence, autonomy, and better living conditions.

The association between IU and some variables studied may be a two-way street. From this research, the risk factors for UI were studied. However, additional longitudinal studies should be performed to establish this relationship, considering that factors that are often considered innocuous can trigger several negative clinical outcomes in long-term institutions.
The limitations of this study were: 1 ) a cross-sectional study which does not allow the establishment of a causeeffect relationship between the variables and, therefore, the data should be carefully analyzed; 2) the research institution is a non-governmental organization, lacking resources and constantly receives elderly people with poor general health, so it is not possible to establish if incontinent elderly people have already been admitted to the problem or have developed in the institution; 3) the MMSE depends on the variable schooling collected, but was not evaluated in this study; 4) UI subtypes were not explored, although defined in the medical records; 5 ) the set of variables for fit could have been a bit more comprehensive, as it is still possible to have residual confounding factors in the analysis.

\section{CONCLUSION}

It was observed a relationship between the independent variables being single, having multiple comorbidities, being a user of polypharmacy, dependent and presenting cognitive decline, predominant determinants for UI in institutionalized elderly.

The results reveal the importance of studying UI in institutionalized elderly, considering the scarce amount of research in Brazil and the reduced clinical approach by health professionals. In addition, the risk factors detected are avoidable, preventable, as long as they are identified early.

Preventing or improving UI through care and attention minimizes mortality rates in institutionalized older people and contributes to better QoL and functional independence.

\section{AUTHORS' CONTRIBUTION}

\section{Conceptualization, Borges CL; Methodology, Borges} $\mathrm{CL}$ and Fernandes BKC; Investigation, Borges $\mathrm{CL}$ and Fernandes BKC; Writing - First version, Borges CL and Menezes LCG; Writing - Reviewing \& Editing, Borges CL, Menezes LCG, Cavalcante MLSN, Barbosa RGB and Peixoto Junior AA.; Acquisition of Financing, Borges CL; Resources, Borges CL; Supervision, Borges CL. 


\section{REFERENCES}

1. Damián J, Pastor-Barriuso R, García López FJ, Pedro-Cuesta J. Urinary incontinence and mortality among older adults residing in care homes. J Adv Nurs. 2017;73(3):688-99. https://doi.org/10.1111/jan.13170

2. Maxwell CJ, Soo A, Hogan DB, Wodchis WP, Gilbart E, Amuah J, et al. Predictors of nursing home placement from assisted living settings in Canada. Can J Aging. 2013;32(4):333-48. https://doi.org/10.1017/S0714980813000469

3. Chiu AF, Huang MH, Hsu MH, Liu JL, Chiu JF. Association of urinary incontinence with impaired functional status among older people living in a long-term care setting. Geriatr Gerontol Int. 2015;15(3):296-301. https://doi.org/10.1111/ ggi.12272

4. Saga S, Vinsnes AG, Mørkved S, Norton C, Seim A. What characteristics predispose to continence in nursing home residents? A population-based cross-sectional study. Neurourol Urodyn. 2015;34(4):362-7. https://doi. org/10.1002/nau.22563

5. Morsch P, Pereira GN, Navarro JHN, Trevisan MD, Lopes DGC, Bós AJG. Clinical characteristics and social determinants in a sample of non-homebound elderly cad. Saúde Publica. 2015;31(5):1025-34. https://doi.org/10.1590/01021$311 \times 00053014$

6. Kwon CS, Lee JH. Prevalence, risk factors, quality of life, and health-care seeking behaviors of female urinary incontinence: results from the 4th Korean National Health and Nutrition Examination Survey VI (2007-2009). Int Neurourol J. 2014;18(1):31-6. https://doi.org/10.5213/ inj.2014.18.1.31

7. Coyne KS, Wein A, Nicholson S, Kvasz M, Chen Cl, Milsom I. Economic burden of urgency urinary incontinence in the United States: a systematic review. J Manag Care Pharm. 2014;20(2):130-40. htps://doi.org/10.18553/ imcp.2014.20.2.130

8. Hrisanfow E, Hägglund D. Impact of cough and urinary incontinence on quality of life in women and men with chronic obstructive pulmonary disease. J Clin Nurs. 2013;22(1-2):97105. https://doi.org/10.1111/j.1365-2702.2012.04143.x

9. Aniuliene R, Aniulis P, Steibliene V. Risk factors and types of urinary incontinence among middle-aged and older male and female primary care patients in Kaunas Region of Lithuania: cross sectional study. Urol J. 2016;13(1):2552-61.

10. Park J, Son Hong G-R. Association of functional ability and benign prostatic hyperplasia with urinary incontinence in older Korean men. Int Neurourol J. 2016;20(2):137-42. https://doi.org/10.5213/inj.1630432.216

11. Léon P, Chartier-Kastler E, Rouprêt M, Ambrogi V, Mozer $P$, Phé $V$. Long-term functional outcomes after artificial urinary sphincter implantation in men with stress urinary incontinence. BJU Int. 2015;115(6):951-7. https://doi. org/10.1111/bju.12848

12. Haylen BT, de Ridder D, Freeman RM, Swift SE, Berghmans B, Lee J, et al. An International Urogynecological Association (IUGA)/International Continence Society (ICS) joint report on the terminology for female pelvic floor dysfunction. Neurourol Urodyn. 2010;29:4-20. https://doi. org/10.1002/nau.20798
13. Jung HB, Kim HJ, Cho ST. A current perspective on geriatric lower urinary tract dysfunction. Korean J Urol. 015;56(4):26675. https://doi.org/10.4111/kju.2015.56.4.266

14. Jerez-Roig J, Souza DLB, Lima KC. Urinary incontinence in institutionalized elderly in Brazil: an integrative review. Rev Bras Geriatr Gerontol. 2013;16(4):865-79. https://doi. org/10.1590/S1809-98232013000400020

15. Mandl M, Halfens RJ, Lohrmann C. Incontinence care in nursing homes: a cross-sectional study. J Adv Nurs. 2015;71(9):2142-52. https://doi.org/10.1111/jan.12676

16. Bertolucci PHF, Brucki SMD, Campacci SR, Juliano Y. The Mini-Mental State Examination in an outpatient population: influence of literacy. Arq de Neuro-Psiquiatr. 1994;52(1):1-7. https://doi.org/10.1590/50004-282X1994000100001

17. Herr M, Grondin H, Sanchez S, Armaingaud D, Blochet C, Vial A, et al. Polypharmacy and potentially inappropriate medications: a cross-sectional analysis among 451 nursing homes in France. Eur J Clin Pharmacol. 2017;73(5):601-8. https://doi.org/10.1007/s00228-016-2193-z

18. Ministério da Saúde (BR). Agência Nacional de Vigilância Sanitária (Anvisa). Resolução da Diretoria Colegiada - RDC/ Anvisa n 283 de 26 de setembro de 2005 [Internet]. Brasília, DF; 2005 [cited 4 Dec 2018]. Available at: http://www20. anvisa.gov.br/segurancadopaciente/index.php/legislacao/ item/rdc-283-de-26-de-setembro-de-2005

19. Brucki SMD, Mansur LL, Carthery-Goulart MT, Nitrini R. Formal education, health literacy and Mini-Mental State Examination. Dement Neuropsychol. 2011;5(1):26-30. https://doi.org/10.1590/S1980-57642011DN05010005

20. Ministério da Saúde (BR). Conselho Nacional de Saúde. Comitê Nacional de Ética em Pesquisa em Seres Humanos. Resolução n 466 de 12 de dezembro de 2012 [Internet]. Brasília, DF; 2012. [citado 4 Dez 2018]. Disponível em: http:// conselho.saude.gov.br/resolucoes/2012/Res0466.pdf

21. Jerez-Roig J, Santos MM, Souza DL, Amaral FL, Lima KC. Prevalence of urinary incontinence and associated factors in nursing home residents. Neurourol Urodyn. 2016;35(1):1027. https://doi.org/10.1002/nau.22675

22. Pitangui ACR, Silva RG, Araújo RC. Prevalence and impact of urinary incontinence on the quality of life of institutionalized elderly women. Rev Bras Geriatr Gerontol. 2012;15(4):61926. https://doi.org/10.1590/S1809-98232012000400002

23. Rosa LHT, Souza CM, Lima CHL, Boggio ESB, Santos FC, Carboni C, et al. Prevalência da incontinência urinária em idosos de Porto Alegre-RS. Geriatr Gerontol Aging. 2014;8(2):104-9.

24. Silva VA, D'Elboux MJ. Factors associated with urinary incontinence in elderly individuals who meet frailty criteria. Texto Contexto Enferm. 2012;21(2):338-47. https://doi. org/10.1590/s0104-07072012000200011

25. Wang C, Wan X, Wang K, Li J, Sun T, Guan X. Disease stigma and intentions to seek care for stress urinary incontinence among community-dwelling women. Maturitas. 2014;77(4):351-5. https://doi.org/10.1016/..maturitas.2014.01.009

26. Hajek A, Brettschneider C, Lange C Posselt T, Wiese $B$, Steinmann $S$, et al. Longitudinal predictors of institutionalization in old age. PLoS One. 2015;10(12):1-11. https://doi.org/10.1371/journal.pone.0144203 
27. Mouodi S, Bijani A, Hosseini SR, Hajian-Tilaki K. Gender differences in the health status of elderly living alone compared to those who are not alone: evidence of the AHAP study, North of Iran. Caspian. J. Intern. Med. 2016;7(2):126-32.

28. Maher RL, Hanlon JT, Hajjar ER. Clinical consequences of polypharmacy in elderly. Expert Opin Drug Saf. 2014;13(1):57-65. https://doi.org/10.1517/14740338.2013. 827660

29. Marques LP, Schneider IJC, Giehl MWC, Antes DL, d'Orsi E. Demographic, health conditions, and lifestyle factors associated with urinary incontinence in elderly from Florianópolis, Santa Catarina, Brazil. Rev Bras Epidemiol. 2015;18(3):595-606.https://doi.org/10.1590/19805497201500030006

30. Griebling TL. Re: Prevalence of commonly prescribed medications potentially contributing to urinary symptoms in a cohort of older patients seeking care for incontinence. J Urol. 2014;192(2):490-1. https://doi.org/10.1016/j. juro.2014.05.083
31. Shaw C, Wagg A. Urinary incontinence in older adults. Medicine. 2017;45(1):23-7. https://doi.org/10.1016/j. mpmed.2016.10.001

32. Schumpf LF, Theill N, Scheiner DA, Fink D, Riese F, Betschart C. Urinary incontinence and its association with functional physical and cognitive health among female nursing home residents in Switzerland. BMC Geriatrics. 2017;17:17. https://doi.org/10.1186/s12877-017-0414-7

33. Cucato GG, Ritti-Dias RM, Cendoroglo MS, Carvalho JMM, Nasri F, Costa MLM, et al. Health-related quality of life in Brazilian community-dwelling and institutionalized elderly: comparison between genders. Rev Assoc Med Bras. 2016;62(9):848-52. https://doi.org/10.1590/18069282.62.09.848

34. Teunissen DT, Stegeman MM, Bor HH, Lagro-Janssen TA. Treatment by a nurse practitioner in primary care improves the severity and impact of urinary incontinence in women. An observational study. BMC Urol. 2015;15:51. https://doi. org/10.1186/s12894-015-0047-0 